\title{
Malcolm Sawyer Claims Advocates of Full Reserve Banking are "Cranks".
}

\author{
Ralph S. Musgrave
}

\begin{abstract}
Giuseppe Fontana and Malcolm Sawyer (F\&S) penned a paper published in the Cambridge Journal of Economics entitled "Full Reserve Banking: More 'Cranks' Than 'Brave Heretics'” (Fontana and Sawyer (2017). The paper basically argued against full reserve banking. The purpose of the paper below is to show that the F\&S paper is riddled with errors. The F\&S paper was answered in the Cambridge Journal of Economics by Dyson, Hodgson and van Lerven (2016)). The latter paper was by its own admission limited in scope: it addressed just four points made by F\&S. The paper below enlarges on the latter paper: i.e. the paragraphs below point to the errors in F\&S's paper missed by or not dealt with by Dyson \& Co (21 errors to be exact). The paper below deals with each error as it occurs. Errors are numbered. Some of the errors are serious, which raises the question as to who the "cranks" are. Another question that arises is: what is a respectable economics journal like the Cambridge Journal of Economics is doing publishing this defective material? I.e. it raises the question as to whether respectable economics journals are really any better than "nonestablishment" journals like Advances in Social Sciences Research Journal. The paper below was not submitted first to the above Cambridge journal because they place a 1,500 word limit on papers which comment on other papers, and 1,500 words is nowhere near enough to deal with the numerous errors made by F\&S.
\end{abstract}

Keywords: "full reserve banking", banking, money, "central banks". JEL classification: E50, E51, E52, E58.

1. F\&S's first section does not say anything particularly controversial. In common with F\&S, the phrase full reserve banking will be shortened to "FRB" in the paragraphs below.

The second section starts by claiming "Much of the advocacy of FRB starts from the observation that around $97 \%$ of money in a modern economy is created by commercial banks, with only the remaining 3\% created by the national central bank. This observation is usually followed by some outrage that it is private banks rather than the publically owned central bank which creates money."

To back up the latter accusations, F\&S then set out some quotes from Dyson and Jackson and Dyson, 2012, and Green Party literature.

Well the problem there, and indeed with the F\&S paper in general, is that Dyson and others with whom Dyson has published sundry works (henceforth "Dyson \& Co") are not the world's leading or most "heavy weight" advocates of FRB: for example there are at least three Nobel laureate economists who have advocated FRB: James Tobin, Maurice Allais and Milton Friedman. Tobin and Allais are not mentioned at all by F\&S, and Friedman gets one mention, but not in connection with his advocacy of FRB. And two other pro-FRB economists who arguably speak with more authority than Dyson, or at least who are worth a mention are Lawrence Kotlikoff and Matthew Klein. (See Tobin (1987, under the heading "Deposited Currency"), Friedman (1960, Ch3, under the heading "Banking Reform", Kotlikoff (2012) and Klein (2013)). 
As for the Green Party, citing them as some sort of authority on FRB, or indeed citing any political party on any economics topic is a strange procedure in a paper in a serious economics journal.

2. Then F\&S claim "A much more serious problem for advocates of FRB is the disregard of established theoretical literatures...".

One answer to that is that Jackson and Dyson (2012), a work which advocates FRB, contains 160 references while $F \& S^{\prime}$ s paper has less than half that number. On that basis, it is reasonable to conclude that Jackson and Dyson are very well acquainted with the literature: at least on the face of it better acquainted than F\&S.

Next, F\&S set out what they claim to be five "analytical errors" in FRB thinking. The first one involves a claim in Daly (2013, p.1)

3. Daly says "Why should the public pay interest to the private banking sector to provide a medium of exchange that the government can provide at little or no cost? And why should seigniorage (profit to the issuer of fiat money) go largely to the private sector rather than entirely to the government (the commonwealth)?"

F\&S's criticism of that passage is that, contrary to Daly's claims, commercial banks which create money do not reap any seigniorage profits.

Well that all depends on exactly what is meant by "seigniorage". If one means the type of profit made by a traditional backstreet counterfeiter (i.e. simply printing hundred dollar bills or similar paper money and spending that money on consumer goods), then clearly commercial banks do not reap that sort of profit. On the other hand Daly simply refers to "profit to the issuer of money", which is much more vague: in fact it is too vague arguably.

Clearly commercial banks must derive some sort of profit from creating money, else they would not do it. So let's just call that "fifteen all": i.e. it is not really clear who is right there: Daly or F\&S.

In contrast, Daly has a very good point when he asks, "Why should the public pay interest to the private banking sector to provide a medium of exchange that the government can provide at little or no cost?"

Daly is right to say that base money can be created to virtually no cost. As Milton Friedman put it, "It need cost society essentially nothing in real resources to provide the individual with the current services of an additional dollar in cash balances." (Friedman (1960, Ch3)

As for Daly's claim that interest has to be paid on commercial bank issued money, that is pretty much correct. To be more accurate, where bank customers want their bank to supply them with money, the bank has to check up on the credit-worthiness of relevant customers and normally requires such customers to deposit collateral / security. That process involves significant costs. In contrast, (and to repeat) issuing base money is virtually costless.

So (to be accurate, or maybe pedantic) where a bank issues money to a customer just to be used as a float, i.e. for day to day purchases (i.e. no sort of permanent loan is involved), then interest (strictly speaking) will not be charged, but a charge will be made for the above costs 
(checking up on credit-worthiness etc). I.e. the latter "checking up" costs really ought to be called administration costs or similar, rather than "interest".

Just to expand on that, where a bank customer borrows $£ Y$ to be used as a float, but the customer subsequently is in debt to the bank as often as the bank is in debt to the customer (because of temporary surpluses of funds deposited by the customer at the bank), then assuming the customer gets interest on the latter deposits and assuming the rate of interest is the same as the bank charges the customer when the customer is in debt to the bank, then over the long term the customer will not pay interest to the bank or vice versa. That is in stark contrast to where a customer obtains for example a mortgage from a bank designed to last twenty years.

4. F\&S's next error is in their sub-section which starts "Inflation can be controlled....". (That's the second of the above mentioned "analytical errors".)

They start by pointing to the similarity between the "create money and spend it" idea put by Dyson \& Co and Milton Friedman's idea that inflation can be controlled by controlling the amount of base money issued, and claim that Friedman's monetarist ideas are now "discredited", which by implication allegedly discredits Dyson \& Co.

Well a problem there is that a number of heavy-weight economists have recently backed Friedman's ideas or at least important elements of those ideas. For example Bernanke (2016 (two paras starting "So how could the legislature...") claimed that a perfectly workable way of controlling demand and inflation would be to have some sort of central bank committee decide how much base money to create and spend, and then leave it to government decide the actual details of how the money was spent (or whether the new money should be used to cut taxes). Plus the deputy governor of Japan's central bank (Iwata) said much the same (Kihara (2019). Plus the former head of the UK's Financial Services Authority, Turner (2016) puts in a good word for "create and spend" sometimes known as "overt money creation" (OMC).

To be exact, there is in fact a difference between Bernanke, Iwata and Dyson on the one hand and Friedman (1948) on the other. Friedman thought governments and central banks were so incompetent that they should have no discretion at all on how much money to create and spend: i.e. he claimed that government should create and spent the same amount as a percentage of GDP every year. In contrast, Bernanke, Iwata, Dyson and indeed nearly every economist thinks governments and central banks should have discretion. However (and to repeat), none of the latter three economists have a problem with $\mathrm{OMC}$, whereas F\&S claim there are big problems there.

5. Moreover, the approving noises made by the latter two senior central bank officials about OMC actually reveals another error made by F\&S, which is that OMC (contrary to the claims of F\&S) does not actually have much to do with FRB: that is, OMC is simply the form of stimulus advocated by Dyson \& Co and some other FRB advocates. I.e. it would be possible to implement FRB while sticking to traditional forms of fiscal and money stimulus. Conversely, and as indicated by the latter two central bank officials, it is perfectly feasible to implement OMC without FRB. Given the large proportion of F\&S's paper devoted to criticising OMC, that is an important defect in their paper.

Having said that, FRB and OMC are inextricably linked in F\&S's paper and no attempt will be made to "unlink" them below. That is, there may be one or two points made about OMC below which arguably should not actually appear below if indeed OMC has nothing to do with FRB. 
The third "analytical error" set out by F\&S is a claim by Dyson \& Co that banks actually determine the quantity and nature of loans. As F\&S rightly say, the quantity and nature of loans is very much a matter of mutual agreement between, or the result of a bargaining process between lenders and borrowers. I.e. that is a point where F\&S are right and which Dyson \& Co are wrong.

6. The next alleged "analytical error" (No4) is plain incomprehensible. It starts with this very strange paragraph, "The new supply of bank loans creates an equal increase in the amount of outstanding debt in the economy. Again, taken at its face value this means that at all times any additional flow of money injected into the economy creates an equally proportionate increase in the total stock of money, as suggested in the quote above."

Well now, it is widely accepted that a bank loan is indeed a debt (owed by the borrower to a bank). Ergo the first sentence in the latter quote is in fact correct! But in the second sentence F\&S appear to disagree with the claim that "any additional flow of money injected into the economy" equals "an equally proportionate increase in the total stock of money". That very much sounds like a self-contradiction!

7. Then in the succeeding paragraph, F\&S say "This view blurs the crucial distinction between money demand, that is, the demand for money to be spent, and liquidity preference, that is, the preference for holding money (hoarding) vis-à-vis other, less liquid assets."

Well the Oxford Dictionary of Economics (2009 edition) starts its definition of Liquidity Preference with the sentence "The preference for holding assets that can most easily be turned into cash." In short, liquidity preference has to do with a range of assets of varying degrees of liquidity, i.e. it is not specifically to do with a particular asset, namely cash, as suggested by F\&S.

8. In their criticism of the fifth alleged "analytical error" made by FRB advocates, F\&S get confused as to the distinction between base money and commercial bank issued money. They say "The growth of money is caused by the growth of output and prices, rather than the reverse."

Yes: that is true of commercial bank created money, but not of base money. That is, increased output will probably result in firms and households requesting more loans from banks, all else equal. But that does not disprove the idea that increasing the stock of base money tends to raise demand and prices: what would happen if the Bank of England printed and distributed a thousand pounds worth of $£ 10$ notes to every household in the UK? There would be a significant increase in demand.

9. The fifth alleged "analytical error" concerns the much debated question as to whether base money is a liability of the central bank, i.e. a debt owed by the central bank.

Dyson \& Co argued that such money is not in fact a liability, while F\&S argue that it is. Dyson \& Co are actually supported by Warren Mosler (founder of Modern Monetary Theory) who claimed that base money is like points in a tennis match: they are assets as far as players are concerned, but not liabilities as far as the umpire, who hands out the points, is concerned.

Another point in favour of the idea that base money is not a liability of central banks is that that so called liability is never actually repaid. That is, the stock of base money in for example the US and UK has risen steadily since WWII and before, with that stock expanding dramatically as 
a result of $\mathrm{QE}$ in the last five years or so. What sort of "liability" or debt is it that is never repaid? Moreover, if government and the central bank are considered as a single unit, that "unit" can wipe out its liabilities at will. That is, government has the power to extort any amount of base money from the private sector whenever it wants via tax. Again, if a debtor can wipe out his or her debt at will, than that's a strange sort of debt.

F\&S do not produce any sort of actual argument to back their claim that base money is a liability of the central bank. Their "argument" simply consists of a series of statements that such money just is a liability. For example they say "Banknotes or monetary reserves are liabilities of the central bank."

10. F\&S then claim that FRB is only aimed at commercial banks, thus, given the large number of financial institutions, there would not be much improvement to the amount of stability.

The reality is that the number of type of institutions which can be made to obey the rules of FRB is very variable, and there are plenty of pros and cons involved in each possible arrangement.

For example, in the US recently, Money Market Mutual Funds were made to obey the rules of FRB, but not commercial banks. In contrast, Adair Turner (former head of the UK's Financial Services Authority) argued that anything that resembles a bank should have to obey the same regulations (though not necessarily FRB regulations). As he put it, "If it looks like a bank and quacks like a bank, it has got to be subject to bank-like safeguards." (See Masters (2012).

Thus if F\&S are concerned about shadow banks and similar "non-regulated" institutions in effect continuing with the existing bank system, the answer is to regulate them! Keeping tabs on every single shadow bank including those with a turnover of less than a million pounds a year might be difficult, but one million a year is a ridiculously small turnover for a bank. As to shadow banks with a turnover of a hundred million, it's a bit difficult to run such a bank and hide your existence from the authorities! Building firms with three employees have to obey health and safety regulations; likewise, relatively small banks or quasi-banks can be made to obey regulations.

Incidentally, the above shadow bank point was one of the four points addressed by Dyson, B., Hodgson, G. and van Lerven, F. (2016).

11. Next, F\&S claim FRB involves what they call a "deflationary bias". That's in their paragraph starting "A second problem with the claimed goal...".

Well certainly if commercial banks are prevented from simply creating the money they lend out from thin air rather than borrowing money first and at interest, then interest rates chartged to those who borrow from banks will probably rise. But there is a very simple answer to that point which is that the real costs of any stimulus needed to counteract that deflationary bias are zero (as implied in the above quote from Friedman). An alleged problem to which the solution involves zero real costs is by definition not a problem!

Incidentally, the latter flawed "deflationary bias" claim by F\&S was dealt with by Dyson, B., Hodgson, G. and van Lerven, F. (2016) (DHVL). The only difference between the answer to F\&S given in the latter paragraph above and that given by DHVL is that DHVL propose, in addition to extra stimulus, the option of the central bank supplying commercial banks with extra funds 
if the supply of credit looks like being constrained too much (aka interest rates rising too far or too fast).

12. Next comes F\&S's paragraph starting "Notwithstanding the considerable debates...”. F\&S claim that in the event of FRB, "herding behaviour could still produce sectoral overinvestment and financial instability". Well the answer to that is that the advocates of FRB have never claimed that FRB produces an entirely defect free economy: the claim is simply that FRB is an improvement on the existing system. As for "overinvestment" and "financial instability" no doubt those to defects would still exist to some extent after introduction of FRB.

13. F\&S's next error is in this passage: "When investment projects are unsuccessful or considered unprofitable, the generation process of income, employment and cash flows suddenly stops, and the economic system is open to the possibility of insolvencies, bankruptcies, deep and long-lasting recessions and financial instability. Therefore, the creation of money through the lending activity of banks is essential in order to accommodate the financing needs of capitalist economies, and to generate the cash flows which will prevent the occurrence of real and financial instabilities."

F\&S's next few sentences then suggest that given the latter potential "bankruptcies" and "recessions", banks heroically come to the rescue by saving potential bankrupt firms and households. Well the obvious problem there is that that is exactly what banks do not do: that is, as is generally accepted by economists, banks act in a pro-cyclical, not an anti-cyclical fashion (regardless of whether they grant loans via the existing bank system or FRB style).

14. Next, F\&S claim "The second inconsistency is that it is not clear where the prior savings alluded to by Daly and other advocates of FRB have come from."

The reality is, contrary to the latter claim by F\&S, that Milton Friedman, Irving Fisher, James Tobin and other advocates of FRB made it abundantly clear decades ago where "where savings come from". Indeed, in the case of Irving Fisher, that point was made clear almost a century ago.

But to repeat the point made by Friedman, Fisher etc, under FRB, the bank industry is split in two. Those who want total safety (or something as near total safety as is possible in this world) effectively place their money with the central bank, where they get little or no interest. As for those who want a significant amount of interest, i.e. those who want to save and have their money invested or loaned on, they buy into a mutual fund: i.e. effectively they buy shares.

That is a serious error by F\&S: it indicates that they do not understand the basics of full reserve. For that reason, the rest of their section 3 will be ignored.

15. At the start of their section 4 , and in contrast to their section 3 where F\&S say they do not understand where savings come from under FRB, F\&S now all of a sudden appear to understand where savings come from. That is, the first paragraph of their section 4 clearly sets out the above mentioned "two types of account" system that is involved under FRB.

Then in the second paragraph, F\&S claim there is a problem with FRB which is that under FRB there is no guarantee that all payments for goods and services will be made with the country's official currency: F\&S quote the case of a country with a weak or chaotic currency where citizens resort to using for example the US dollar. 
Well the first answer to that is that the advocates of FRB ever since FRB was first proposed have been concerned almost exclusively with normal European and North American countries. At the other end of the scale there are of course the Zimbabwies of this world where citizens resort to using US dollars. But the latter sort of economy is very much a separate issue which will not be further considered here.

Moreover, F\&S do not explain why anyone would want to use a currency other than the relevant country's official currency. In particular, since the aim under FRB is to supply the private sector with whatever amount of currency induces the private sector to spend at a rate that brings full employment, it is not clear why households or firms in that scenario would want access to more money.

Of course there is the point that interest rates would tend to be higher under FRB, thus banks in other countries which operated a conventional bank system might be tempted to try to lend to borrowers in the FRB country. But assuming the law is enforced in the FRB country, any incoming banks would have to operate under FRB rules, thus lending at a lower rate than domestic banks would not be easy.

16. Next, in the paragraph starting "Transaction accounts would be costly...", F\&S make the complaint which has been made by several other critics of FRB, namely that transaction accounts would be more expensive for depositors since it would not be possible for banks to defray the cost of running those accounts with interest earned from loans made by the bank. (For earlier examples of that "complaint", see Musgrave (2014, section 2.12)

Well the answer to that is that if one of the products you currently purchase, $\mathrm{X}$, is cross subsidised by another, product $Y$, and the cross subsidisation stops, the price of $X$ will rise and the price of Y will fall. But on balance, that won't leave the average consumer much worse or better off.

That is, if instead of being able to have their instant access money loaned out, bank customers have to split their money between interest earning money and zero interest earning and instant access / transaction money, that won't make much difference to the net costs of their bank accounts (or net income from such accounts in the case of those who invest more than average in investment accounts).

17. Next, and in the same paragraph, F\&S argue that banks will try to get round the two account system by offering depositors more or less instant access money from their investment accounts. Well certainly under FRB, depositors would be free to sell their shares or stakes in investment account funds whenever they want, and banks would have an incentive to make that process as quick as possible. But by the same token, anyone is free to sell a house, car, piece of furniture or stock exchange quoted shares whenever they want. That does not make houses or cars a form of money.

Also that in no way degrades the basic purpose of investment accounts, namely that if a bank makes silly loans, the value of the stakes in relevant investment account funds will fall, thus it is impossible for the bank itself to go bust as a result of those silly loans.

Incidentally, the phrase "investment account funds" was used there for the following reasons. While it would be possible under FRB for a bank to offer just one type of investment account which funded a variety of different loans and investments, an alternative, advocated by several proponents of FRB is for a bank to offer a VARIETY of different funds (effectively mutual funds 
/ unit trusts) which "investors" can invest in. The latter strategy has obvious advantages for investors: for example those who want near total safety could invest in a fund that just funded ultra-safe bog standard mortgages, for example, mortgages where house owners had a significant equity stake.

18. The first paragraph of F\&S's fifth section starts by pointing out (correctly) that "It is a fundamental feature of the present system that government expenditure may be restrained by several factors (e.g. political preferences, lack of idle resources), but under no circumstances is it constrained by a lack of finance." In other words a government and its central bank (in a country which issues its own currency) can create and spend as much money as government wants: if they really want, they can "do a Zimbabwe" and create and spend ludicrous amounts of money.

But F\&S then say "How much of the newly created money remains in the private sector depends on the extent of the reflux mechanism."

Actually the reflux mechanism is the process via which when commercial bank customers find they have an excess stock of money / loans from such banks, they simply repay some of those loans. As Hortlund (2006) puts it "There is a "law of reflux" at work, whereby unwanted money is always returned to the issuer-banks therefore do not have the power to over-issue money and can therefore never be the cause of inflation."

But that process does not apply to base money, i.e. central bank issued money. To illustrate, if someone has $£ X$ in their commercial bank as a result of selling $£ X$ worth of UK government debt to the Bank of England as part of QE (with the relevant commercial bank of course having $£ X$ of reserves at the BoE to match), there is no way the private sector as a whole can dispose of that $£ X$ : only the BoE can reduce the amount of base money / reserves. And that is a serious error: it calls into question just how much of a grasp of basic banking (including central banking operations) F\&S have.

It could be argued that a roughly similar "reflux type" process applies to base money: that is, given an excess supply of base money in the hands of the private sector, the result is likely to be excess spending by the private sector and thus excess inflation. Thus the central bank and/or government will be tempted to mop up some of that excess money, e.g. via interest rate hikes or tax increases. But that is certainly not what is normally meant by the phrase "reflux mechanism".

19. In the third paragraph of section 5 , and having admitted that public spending is constrained by "lack of idle resources", F\&S say "In short, under FRB a distinct limit which is placed on the money creation process, namely that the central bank adopts a monetarist rule and commercial banks do not create money, feeds back onto constraints on the willingness of the central bank to finance government expenditure."

Well that suggestion, namely that under FRB, the central bank can constrain public spending is nonsense because there is nothing to stop government raising public spending and paying for that with more tax!

20. F\&S's then nicely illustrate their non-grasp of this subject with this passage (section 5.1): "Furthermore, the imposition of a constraint on the budget deficit (or surplus) to be achieved in a specific time period faces two problems. The first of the problems comes from asking the 
question as to what reason there is to think that the pre-specified budget position target is compatible with a high level of employment."

Well the obvious answer to that is that under FRB, much as under the existing system, government pitches the "pre-specified budget position" (aka the deficit) at whatever level it thinks will keep unemployment as low as is consistent with acceptable inflation. Of course, under FRB, government is no more likely to get that right than under the existing system, so that particular point is not a point for or against FRB.

21. Then F\&S claim (their section 5.1) that under FRB, central banks dominate fiscal policy with democratically elected politicians losing control thereof. In their section $5, \mathrm{~F} \& S$ say "The central bank imposes a target growth for the stock of money for the coming time period, say a year, and that in turn imposes a target for the budget deficit. Thus, fiscal policy becomes completely subordinated to monetary policy."

Similarly in their "Concluding remarks" section 6, they say, “...an FRB will nullify the automatic stabilisers of fiscal policy and lead to a dominance of monetary policy and unelected central bankers over fiscal policy and democratic decision making."

That is actually a very common criticism of FRB: one which has been demolished a dozen times in the literature, e.g. see Musgrave (2014, section 2.10). That supports the point made at the outset above, that if anyone is not acquainted with the literature, it is F\&S rather than FRB advocates.

F\&S clearly do not understand the basics of FRB (at least as proposed by Dyson \& Co). In particular, they do not get the point that under FRB those "unelected central bankers" simply decide the size of the deficit, while decisions of a strictly political nature, like what proportion of GDP is allocated to public spending and how that is split between education, health etc remains with politicians. Incidentally, that mistake by F\&S was addressed by DHVL in their response to $\mathrm{F} \& \mathrm{~S}$.

As regards the above mentioned "automatic stabilisers", F\&S do have a slightly better point. That is, if the central bank declared for example that a deficit of $£ Z$ was suitable over the next year, and the economy was hit by a recession say three months after that declaration, plus the central bank insisted that government stuck to the latter deficit, i.e. the central bank refused to let the automatic stabilisers work, then clearly that would be counter-productive.

However, those who determine the size of the deficit under the existing system are not that stupid, nor would they be that stupid under FRB. That is, it clearly does not make sense to try to determine the size of the deficit a year or two in advance, and refuse to change the size of the deficit if a recession hits in the meantime.

\section{References}

Bernanke, B.S. 2016. What tools does the Fed have left? Part 3: Helicopter money. Brookings. https://www.brookings.edu/blog/ben-bernanke/2016/04/11/what-tools-does-the-fed-have-left-part-3helicopter-money/

Daly, H. 2013. Nationalize money, not banks. Centre for the Advancement of the Steady State Economy. https://steadystate.org/nationalize-money-not-banks/

Dyson, B., Hodgson, G. and van Lerven, F. 2016. A response to critiques of 'full reserve banking', Cambridge Journal of Economics, vol. 40, no. 5, 1351-61.

doi:10.1093/cje/bew036 
Fontana, G. and Sawyer, M. 2016. Full Reserve Banking: More 'Cranks' Than 'Brave Heretics'. Cambridge Journal of Economics.

doi: 10.1093/cje/bew013

Friedman, M. 1948. A monetary and fiscal framework for economic stability. American Economic Review, 38, 245-264.

https://miltonfriedman.hoover.org/friedman_images/Collections/2016c21/AEA-AER_06_01_1948.pdf

Friedman, M. 1960. A Program for Monetary Stability. New York: Fordham University Press.

Hortlund, P. 2006. Defense of the Real Bills Doctrine. Econ Journal Watch, Volume 3, Number 1, January 2006, pp 73-87.

https://econjwatch.org/articles/in-defense-of-the-real-bills-doctrine

Jackson, A. and Dyson, B. 2012. Modernising Money: Why Our Monetary System Is Broken and How It Can Be Fixed, London: Positive Money.

Kihara, L. 2019. Architect of BOJ stimulus calls for big fiscal spending backed by central bank. Reuters. https://www.reuters.com/article/japan-economy-boj/architect-of-boj-stimulus-calls-for-big-fiscal-spendingbacked-by-c-bank-idUSL3N20D016

Klein, M. 2013. The Best Way to Save Banking Is to Kill It. Bloomberg. https://www.bloomberg.com/opinion/articles/2013-03-27/the-best-way-to-save-banking-is-to-kill-it

Kotlikoff, L. 2012. The Economic Consequences of the Vickers Commission. London. Civitas. https://www.kotlikoff.net/files/consequences_vickers.pdf

Masters, B. 2012. FSB seeks tame shadow banking. Financial Times. https://www.ft.com/content/23eefd10-3175-11e2-b68b-00144feabdc0

Musgrave, R.S. 2014. The Solution is Full Reserve / 100\% Reserve Banking. KSP books. http://books.ksplibrary.org/978-605-2132-59-3/

Tobin, J. 1987. The case for preserving regulatory distinctions. Proceedings " Economic Policy Symposium, Jackson Hole. pp.167-205.

https://www.kansascityfed.org/publicat/sympos/1987/s87tobin.pdf

Turner, A. 2016. Adair Turner: Making sense of 'helicopter money'. World Economic Forum.

https://www.weforum.org/agenda/2016/08/adair-turner-making-sense-of-helicopter-money/ 